RAV KOOK 


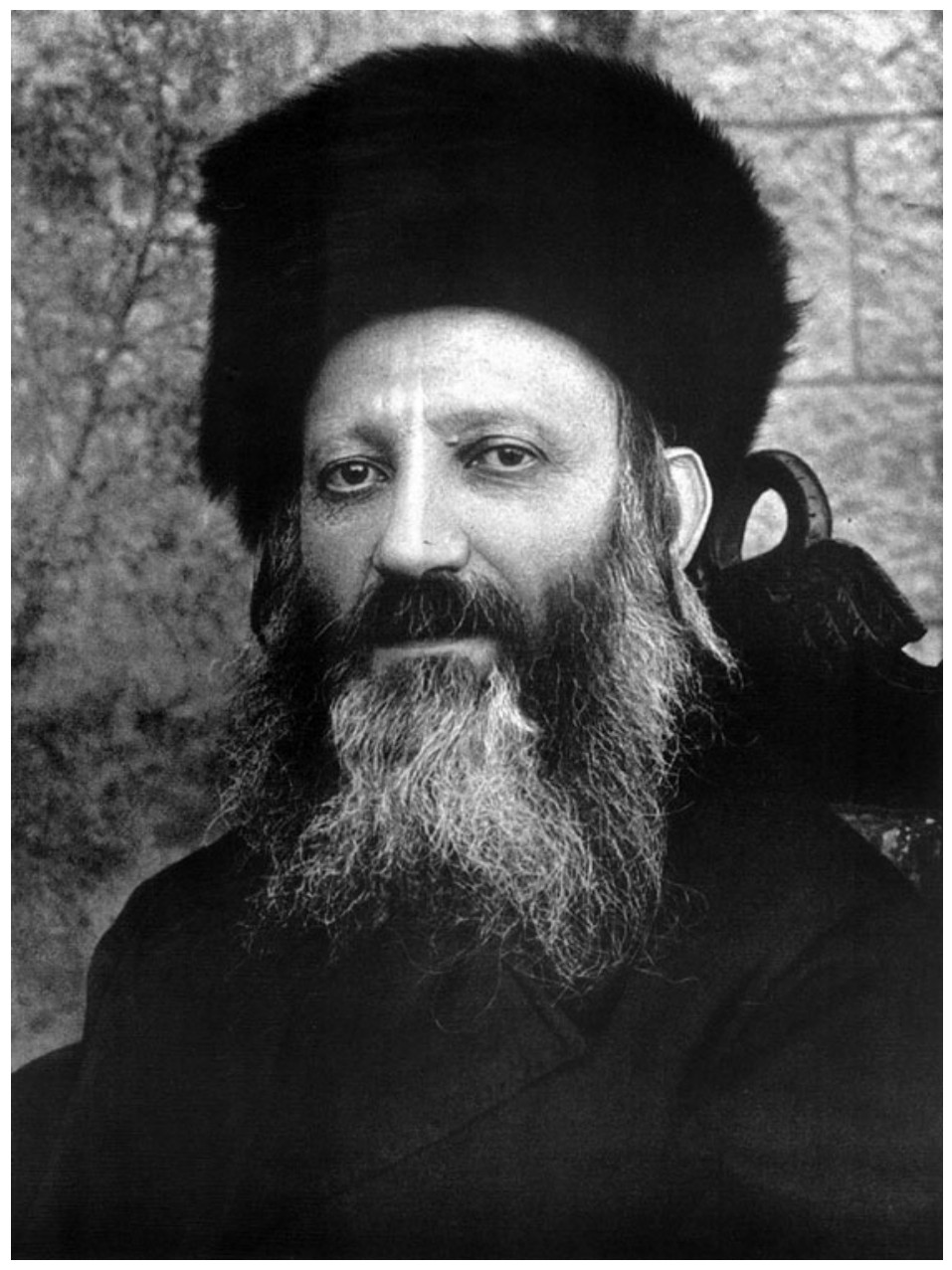




\section{Rav Kook}

Mystic in a Time of Revolution

YEHUDAH MIRSKY

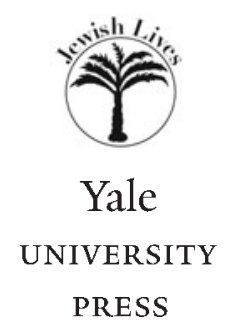

New Haven and London 
Frontispiece: Rav Kook, in Jerusalem during the years of his chief rabbinate.

\section{Copyright (C) 2014 by Yehudah Mirsky.}

All rights reserved.

This book may not be reproduced, in whole or in part, including illustrations, in any form (beyond that copying permitted by Sections 107 and 108 of the U.S. Copyright Law and except by reviewers for the public press), without written permission from the publishers.

Yale University Press books may be purchased in quantity for educational, business, or promotional use. For information, please e-mail sales.press@yale.edu (U.S. office) or sales@yaleup.co.uk (U.K. office).

Set in Janson type by Integrated Publishing Solutions. Printed in the United States of America.

Library of Congress Cataloging-in-Publication Data

Mirsky, Yehudah, author.

Rav Kook : mystic in a time of revolution / Yehudah Mirsky.

pages $\mathrm{cm}$. - (Jewish lives)

Includes bibliographical references and index.

ISBN 978-0-300-I6424-4 (hardback)

I. Kook, Abraham Isaac, I865-I935. 2. Rabbis-Biography. 3. RabbisJerusalem-Biography. I. Title.

$$
\begin{gathered}
\mathrm{BM}_{755} \cdot \mathrm{K}_{66} \mathrm{M}_{57}{ }_{2013} \\
{ }_{296.8}{ }_{32092-\mathrm{dc} 23}
\end{gathered}
$$

2013026566

A catalogue record for this book is available from the British Library.

This paper meets the requirements of ANSI/NISO Z39.48-1992

(Permanence of Paper).

$$
\text { I0 } 98765432 \text { I }
$$


In memory of my father, Rabbi Professor David Mirsky zt'l And in honor of my mother, Sarrah Appel Mirsky כי באור פניכם נתתם לי תורת חיים ואהבת חסד, צדקה וברכה 
Do I contradict myself?

Very well then ... I contradict myself;

I am large ... I contain multitudes.

-Walt Whitman

Our only resting place is in God.

-Avraham Yitzhak Kook 